\title{
Bacterial growth in experimental plankton assemblages and seawater cultures from the Phaeocystis antarctica bloom in the Ross Sea, Antarctica
}

\author{
Hugh Ducklow $^{1, *}$, Craig Carlson ${ }^{2}$, Walker Smith ${ }^{1}$ \\ ${ }^{1}$ Virginia Institute of Marine Science, The College of William and Mary, PO Box 1346, Gloucester Point, \\ Virginia 23062-1346, USA \\ ${ }^{2}$ Bermuda Biological Station for Research, Ferry Reach, St. George's GE01, Bermuda
}

\begin{abstract}
A series of seawater culture experiments was carried out during the Phaeocystis antarctica bloom in the Ross Sea polynya $\left(76.5^{\circ} \mathrm{S}, 180^{\circ} \mathrm{W}\right.$; November to December 1994 and December 1995 to January 1996) to examine bacterioplankton growth and derive empirical factors for estimating bacterial production rates. Bacterial growth was exponential over 3 to $10 \mathrm{~d}$ in all experiments, at rates of ca 0.1 to $0.7 \mathrm{~d}^{-1}$, even in persistently cold waters $\left(-2\right.$ to $\left.+1^{\circ} \mathrm{C}\right)$. Growth rates were lower in the early part of the bloom (early to mid-November) and highest during the period of peak primary productivity ( 2 to $4 \mathrm{~g} \mathrm{C} \mathrm{m}^{-2} \mathrm{~d}^{-1}$ in late November through December). Apparent lag phases in the growth curves lasting 1 to $7 \mathrm{~d}$ could be accounted for mathematically by subpopulations in the bacterial assemblages growing exponentially at different rates, with no need to invoke inactive, nondividing or nonviable populations. Lags were absent during the period of peak primary production, suggesting adaptation of the bacteria to ambient DOM. Growth was not stimulated by small temperature increases $\left(\Delta+2\right.$ to $\left.4^{\circ} \mathrm{C}\right)$, and was not balanced by removal processes in untreated 'whole' water samples. Growth rates were broadly similar to other directly observed bacterial growth rates in the Antarctic and did not appear to differ from rates in warmer waters. Conversion factors for thymidine and leucine averaged 8 and $0.8 \times 10^{17}$ cells $\mathrm{mol}^{-1}$, respectively, not dissimilar to estimates from temperate waters. These findings suggest that bacteria were growing actively in 0 to $-2^{\circ} \mathrm{C}$ waters under rich bloom conditions, and lend strong support to the hypothesis that bacterioplankton metabolism controls DOC accumulation in Antarctic waters, at least at the low rates of DOM supply we infer from field and experimental observations. Bacterioplankton responded within 10 to $20 \mathrm{~d}$ to the evolving $P$. antarctica bloom and did not appear to behave substantially differently from lower latitude bloom systems.
\end{abstract}

KEY WORDS: Bacterioplankton - Microbial foodweb - Carbon cycle - Antarctica P Phaeocystis

\section{INTRODUCTION}

The Southern Ocean occupies a large part of the marine biosphere and plays an important role in the global carbon cycle (Sarmiento \& Toggweiler 1984, Sarmiento \& Le Quére 1996). However we lack a firm quantitative, observational basis to serve as a foundation for these statements, and the models from which they are derived. Marginal ice zones (MIZ) within the

\footnotetext{
•E-mail: duck@vims.edu
}

Southern Ocean are regimes characterized by large seasonal pulses of primary productivity and vertical fluxes to the sediments (Smith \& Nelson 1985, DeMaster et al. 1991). The significance of biogeochemical processes in these MIZ regimes is not established, partly because of a paucity of modern biogeochemical studies on the carbon cycle, and partly because the role of ocean margin systems generally is still poorly understood as well as controversial (Mantoura et al. 1991, Smith \& Hollibaugh 1993).

The role of bacterioplankton in the carbon cycle of the Southern Ocean and MIZ within it is still very far 
from clear as well. For example, Karl (1993) concluded that bacterial utilization was uncoupled from primary production, and that autotrophic-heterotrophic relationships were fundamentally different from other habitats. In contrast, Billen \& Becquevort (1991) concluded that a lag or delay in bacterial response to phytoplankton blooms in Antarctic waters was not unusual and could be explained by the same mechanism as is found in temperate regimes (i.e. that lags were a consequence of bacterial dependence on polymeric materials released by algae, which required enzymatic hydrolysis before they could be utilized). Azam et al. (1991) also pointed out several features of the Antarctic microbial loop which indicated uniqueness of microbial foodwebs in the region. They hypothesized that the Southern Ocean experienced an accumulation of slow-to-degrade dissolved organic matter (DOM) which would fuel bacterial production through the winter. Karl (1993) pointed out that the range of bacterial biomass and rate measurements in Antarctic waters spanned the entire range of values made elsewhere, suggesting 'nothing inherently unique' about Antarctic microbial functioning. Finally Carlson et al. (1998) showed that bacterial production was a small fraction of primary production $(<10 \%)$ in the Ross Sea, and inferred that bacterial metabolism was severely limited by low substrate supply even during the height of the Phaeocystis antarctica bloom.

We began comprehensive studies of bacterial dynamics in the Ross Sea with the objective of reconciling some of these views. The Ross Sea polynya is the site of the most spatially extensive phytoplankton bloom in the Southern Ocean (Sullivan et al. 1993). Physical dynamics in the region make the bloom reliably predictable in space and time, facilitating oceanographic observations (Smith \& Gordon 1997). The bloom is perennially dominated by Phaeocystis antarctica, a large colonial haptophyte, which reaches biomass levels of $15 \mathrm{mg}$ chlorophyll (chl) $\mathrm{m}^{-3}$, with primary production rates exceeding $4 \mathrm{~g} \mathrm{C} \mathrm{m}^{-2} \mathrm{~d}^{-1}$ (Smith \& Gordon 1997), In the North Sea, massive blooms of $P$. pouchetti produce copious amounts of mucus and large aggregates, as well as large fluxes of dissolved organic carbon (DOC) (Lancelot et al. 1998). By analogy with the North Sea system, and the predictions of Azam et al. (1991), we initially hypothesized that the $P$. antarctica bloom in the Ross Sea would also lead to large DOC accumulations which in turn would sustain high bacterial activity. To our surprise, we have not observed large DOC accumulations during and following the bloom. Unlike other Phaeocystis-dominated systems, the Ross Sea bloom is largely dominated by particles rather than dissolved materials (Carlson et al. 1998). The lack of DOM accumulation seems to be a consequence of control exerted by bacterial utilization and low DOM release rates. Smith et al. (1998) suggest that copious DOM release can occur, but only following nutrient depletion, which is generally prevented by iron limitation in situ (Sedwick \& DiTullio 1997). In general, nutrient depletion does not occur and DOM release rates are modest at best in our study region.

Conclusions about bacterial carbon cycling depend on the validity of extrapolations which can be made from experimental observations of water column rates of thymidine and leucine incorporation, and of precise estimates of growth (conversion) efficiencies and the carbon content of bacterial cells (Ducklow \& Carlson 1992). While there have been several reports of bacterial production using empirically derived conversion factors for the Antarctic (Billen \& Becquevort 1991, Bjørnsen \& Kuparinen 1991, Lochte et al. 1997), the details of bacterial growth relationships with incorporation rates have not usually been described. Thus it is difficult to evaluate the precision of the results. In this paper, we describe in detail the nature and rates of bacterial growth in Ross Sea samples. In a companion paper new experimental techniques for specifying conversion efficiencies and carbon biomass will be described (Carlson et al. 1999, in this issue), leading to a synthesis of extensive field observations.

\section{METHODS}

Study area and experimental design. Sampling for these experiments was carried out during 2 cruises of the Research Vessel-Ice Breaker (RVIB) 'Nathaniel B. Palmer' in the southern Ross Sea, mostly along the latitude $76.5^{\circ} \mathrm{S}$ in November to December 1994 and December 1995 to January 1996. Most sampling was in or near the Ross Sea polynya (Smith \& Gordon 1997. Carlson et al. 1998), which was characterized by thinning and discontinuous ice cover in 1994, and primarily by open water in 1995-96. Surface layer water temperatures ranged from -1.9 to $0^{\circ} \mathrm{C}$ during our cruises. There was continuous $24 \mathrm{~h}$ daylight during both cruises. Sampling locations, environmental and bacterological data and experimental treatments are given in Tables 1 \& 2.

Our general approach was to conduct a series of seawater culture experiments (Ammerman et al. 1984) with various experimental treatments to estimate bacterioplankton growth rates and conversion factors for deriving production estimates from ${ }^{3} \mathrm{H}$-thymidine (TdR) and ${ }^{3} \mathrm{H}$-leucine (Leu) incorporation rates. Most samples were size-fractionated and incubated in the dark to remove bacteriovores and minimize sources of newly produced DOM, thereby requiring the bacterial populations to grow on the ambient DOM pools (Carlson et al. 1999). Some samples were grown in un- 
Table 1. Incubation experiments conducted in the Ross Sea in austral spring-summers of 1994 and 1995. na: not applicable

\begin{tabular}{|c|c|c|c|c|c|c|c|c|c|c|c|c|}
\hline \multirow{2}{*}{$\begin{array}{l}\text { Expt } \\
\text { Carboy 94-1 }\end{array}$} & \multirow{2}{*}{$\begin{array}{l}\text { Lat. } \\
\left({ }^{\circ} \mathrm{S}\right) \\
76.52\end{array}$} & \multirow{2}{*}{$\begin{array}{c}\text { Long. } \\
179.91^{\circ} \mathrm{W}\end{array}$} & \multirow{2}{*}{$\begin{array}{c}\text { Depth } \\
\text { (m) } \\
20\end{array}$} & \multicolumn{2}{|c|}{$\begin{array}{l}\text { Temp. Chl a } \\
\left({ }^{\circ} \mathrm{C}\right)\left(\mu \mathrm{g} \mathrm{l}^{-1}\right)\end{array}$} & \multicolumn{2}{|c|}{$\begin{array}{l}\text { Bact. abund. } \\
\left(10^{8}{\left.\text { cells } l^{-1}\right)}\right. \\
\text { Before }{ }^{a} \text { After }\end{array}$} & \multicolumn{2}{|c|}{$\begin{array}{l}\text { DOC }(\mu \mathrm{M}) \\
\text { Before After }\end{array}$} & \multirow{2}{*}{$\begin{array}{l}\text { Treatment } \\
\text { Whole water }\end{array}$} & \multicolumn{2}{|c|}{$\begin{array}{l}\text { Incubation } \\
\text { conditions }\end{array}$} \\
\hline & & & & -1.80 & 2.7 & 1.28 & 1.28 & 45.5 & $45.5^{\mathrm{b}}$ & & Deck, light & $+1^{\circ} \mathrm{C}$ \\
\hline Carboy $94-2$ & 76.48 & $173.17^{\circ} \mathrm{E}$ & 10 & -1.86 & $<2$ & 1.01 & 1.06 & 41.7 & 53.4 & $0.8 \mu \mathrm{m}$ filtrate & Dark & $-2^{\circ} \mathrm{C}$ \\
\hline Carboy $94-3$ & 76.49 & $172.84^{\circ} \mathrm{E}$ & 10 & -1.76 & 5.0 & 2.08 & 1.18 & 42.0 & 53.4 & $0.8 \mu \mathrm{m}$ filtrate & Dark & $-2^{\circ} \mathrm{C}$ \\
\hline Carboy $94-3 G$ & 76.49 & $172.84^{\circ} \mathrm{E}$ & 10 & -1.76 & 5.0 & 2.08 & 1.18 & 42.0 & & $\begin{array}{c}0.8 \mu \text { m filtrate } \\
\text { tglucose }\end{array}$ & Dark & $-2^{\circ} \mathrm{C}$ \\
\hline Carboy $94-4$ & 77.17 & $173.92^{\circ} \mathrm{E}$ & 10 & -1.75 & 3.8 & 2.13 & 2.13 & 43.6 & $43.6^{\mathrm{b}}$ & Whole water & Deck, light & $+1^{\circ} \mathrm{C}$ \\
\hline Carboy $94-5$ & 75.27 & $174.80^{\circ} \mathrm{E}$ & 20 & -1.68 & 5.5 & 3.49 & 1.56 & 42.9 & 51.8 & $0.8 \mu \mathrm{m}$ filtrate & Dark & $-2^{\circ} \mathrm{C}$ \\
\hline Carboy $94-52^{\circ}$ & 75.27 & $174.80^{\circ} \mathrm{E}$ & 20 & -1.68 & 5.5 & 3.49 & 1.56 & 42.9 & 52.0 & $0.8 \mu \mathrm{m}$ filtrate & Dark & $+2^{\circ} \mathrm{C}$ \\
\hline Carboy $94-5 \mathrm{~W}$ & 75.27 & $174.80^{\circ} \mathrm{E}$ & 20 & -1.68 & 5.5 & 3.49 & 3.49 & 42.9 & $64.8^{c}$ & Whole water & Dark & $-2^{\circ} \mathrm{C}$ \\
\hline Bag 95-1 & 76.50 & $177.69^{\circ} \mathrm{E}$ & 5 & -1.29 & 8.6 & 3.24 & 1.50 & 43.8 & 60.1 & $0.8 \mu \mathrm{m}$ filtrate & Dark & $0^{\circ} \mathrm{C}$ \\
\hline Bag 95-1. $2^{\circ}$ & 76.50 & $177.69^{\circ} \mathrm{E}$ & 5 & -1.29 & 8.6 & 3.24 & 1.50 & 43.8 & 56.4 & $0.8 \mu \mathrm{m}$ filtrate & Dark & $+2^{\circ} \mathrm{C}$ \\
\hline Carboy 95-1 & 76.49 & $168.47^{\circ} \mathrm{E}$ & 15 & -1.31 & 7.4 & 12.2 & 4.13 & 43.9 & $43.9^{\mathrm{b}}$ & Whole water & Deck, light & $+1^{\circ} \mathrm{C}$ \\
\hline Bag 95-2 & 76.50 & $164.96^{\circ} \mathrm{E}$ & 10 & -0.95 & 3.5 & 1.85 & 1.60 & 47.8 & 52.4 & $0.8 \mu \mathrm{m}$ filtrate & Dark & $0^{\circ} \mathrm{C}$ \\
\hline Bag 95-3 & 76.50 & $176.69^{\circ} \mathrm{E}$ & 15 & -0.28 & $<2$ & 6.98 & 3.20 & 44 & na & $0.8 \mu \mathrm{m}$ filtrate & Dark & $0^{\circ} \mathrm{C}$ \\
\hline
\end{tabular}

treated 'whole' water samples incubated in surfacewater-cooled, screened deck incubators at ambient near surface temperature and irradiance. The effects of incubation in near-surface irradiance levels seemed to be limited to chlorophyll bleaching over the first few days of the incubations (Smith et al. 1998). We also performed 2 temperature manipulation experiments and 1 glucose addition experiment (Table 1). Samples were collected from hydrocasts with modified $10 \mathrm{l}$ Niskin bottles equipped with silicone O-rings and Tefloncoated stainless steel springs.

Sample preparation and subsampling. Immediately following collection, samples were either transferred to acid-washed, 201 , spigoted polycarbonate carboys (Nalgene) for whole-water experiments, or size-fractionated by gravity filtration through $145 \mathrm{~mm}$ diame. ter, $0.8 \mu \mathrm{m}$ pore size mixed ester filters (Costar) held in specially constructed large diameter PVC filter holders. Filters were flushed with several liters of Nanopure water and several hundred $\mathrm{ml}$ of sample to remove potential DOM leachates prior to sample collection. The filtrate was collected in sample-rinsed polycarbonate carboys. Sample processing was carried out in reduced light at low temperature (ca $0^{\circ} \mathrm{C}$ ) over 1 to $2 \mathrm{~h}$. Pre- and post-filtration samples or ambient water samples were taken to characterize ambient source populations (Tables $1 \& 2$ ). Removal of bacteria by filtration was variable depending on abundance and cell sizes, ranging from 0 to $50 \%$ (Table 1). Except for Carboy experiments 94-1, 94-4 and 95-1 (Table 1) incubated on deck, all carboys and bags were incubated in refrigerated growth chambers in the ship's main lab. Large incubation volumes (15 to 20 l) buffered the samples from temperature changes during brief subsampling periods. The accuracy and precision of temperature in the growth chambers was $\pm 0.5^{\circ} \mathrm{C}$. Several samples were incubated in 20 to $36 \mathrm{l}$ gas tight trilaminate bags (Table 1; Carlson et al. 1999) held in chilled water baths in the ship's cold room. Most experiments were sampled initially at time zero and ca $12 \mathrm{~h}$ later, and then near midday every 1 to $2 \mathrm{~d}$ for bacterial abundance and cell volume, $\mathrm{TdR}$ and Leu incorporation, DOC, nutrients, and in the whole water incubations, chl $a$, POC, PN and other properties (Smith et al. 1998).

Measurements. Water from the incubation carboys or bags was subsampled into acid-cleaned, samplerinsed plastic bottles for further analysis. Samples for bacterial abundance and size measurements were preserved with cell-free $1 \%$ glutaraldehyde, filtered within $2 \mathrm{~d}$ onto black $0.2 \mu \mathrm{m}$ polycarbonate membranes, stained with $0.005 \%$ acridine orange, mounted in Resolve immersion oil on slides and stored frozen until image analysis at VIMS (Virginia Institute of Marine Science). Volume filtered was varied to deposit ca 100 to 300 cells within a video microscopy field. All samples were examined directly after mounting to check cell distribution and image quality. Abundance and cell sizes were determined using video image analysis on a Zeiss Axiophot epifluorescence microscope. Image analysis followed the protocol described in Ducklow et al. (1992). Cell volume is estimated from the area and perimeter of cell 
Table 2. Initial properties and yields during incubation experiments. TdR: ${ }^{3} \mathrm{H}$-thymidine, Leu: ${ }^{3} \mathrm{H}-\mathrm{leucine}$, na: not applicable

\begin{tabular}{|c|c|c|c|c|c|c|c|c|c|c|}
\hline Expt & Treatment & Days $^{a}$ & $\begin{array}{l}\text { Initial } \\
\text { abund. } \\
\left(10^{8} \mathrm{c}\right.\end{array}$ & $\begin{array}{l}\text { Yield } \\
\text { (abund.) }^{b} \\
\text { lls } l^{-1} \text { j }\end{array}$ & $\begin{array}{l}\text { Initial } \\
\text { biovol. } \\
\left(10^{6} \mu \mathrm{n}\right.\end{array}$ & $\begin{array}{l}\text { Yield } \\
(\text { vol. })^{c} \\
\left.3^{3} l^{-1}\right)\end{array}$ & $\begin{array}{c}\text { Initial } \\
\text { TdR incorp. } \\
(\mathrm{pM}\end{array}$ & $\begin{array}{l}\text { Initial } \\
\text { Leu incorp. } \\
\mathrm{h}^{-1} \text { ) }\end{array}$ & $\begin{array}{l}\text { Sp.inc. } S \\
\text { TdR } \\
\left(10^{-21} \mathrm{~mol} \mathrm{~h}^{-}\right.\end{array}$ & $\begin{array}{l}\text { Sp. inc. } \\
\text { Leu } \\
\left.\mathrm{h}^{-1} \text { cell }^{-1}\right)\end{array}$ \\
\hline Carboy 94-1 & Whole & 14 & 0.99 & 12.5 & 3.25 & 81.3 & na & na & na & na \\
\hline Carboy 94-2 & $<0.8 \mu \mathrm{m}$ & 7 & 1.06 & 9.9 & 4.35 & 36.9 & 0.17 & 5.42 & 1.58 & 51.24 \\
\hline Carboy 94-3 & $<0.8 \mu \mathrm{m}$ & 10 & 1.18 & 14.2 & 4.43 & 86.5 & 0.21 & 3.75 & 1.80 & 31.66 \\
\hline Carboy 94-3G & $\begin{array}{l}<0.8 \mu \mathrm{m} \\
+ \text { glucose }\end{array}$ & 10 & 1.11 & 8.4 & 4.12 & 43.4 & 0.17 & 2.40 & 1.56 & 21.55 \\
\hline Carboy 94-4 & Whole & 10 & 2.13 & 7.8 & 8.97 & 42.0 & 0.65 & 5.80 & 3.05 & 27.23 \\
\hline Carboy 94-5 & $<0.8 \mu \mathrm{m}$ & 4 & 1.56 & 17.8 & 7.24 & 99.8 & 4.02 & na & 25.73 & na \\
\hline Carboy $94-52^{\circ}$ & $<0.8 \mu \mathrm{m}+2^{\circ} \mathrm{C}$ & 4 & 1.56 & 22.7 & 7.24 & 84.2 & 1.99 & na & 12.75 & na \\
\hline Carboy 94-5W & Whole & 2 & 3.49 & 1.7 & 17.7 & 9.3 & na & na & na & na \\
\hline Mean & All treatments & 7.6 & 1.64 & 11.9 & 7.06 & 69.4 & 1.20 & 4.34 & 7.74 & 32.92 \\
\hline $\mathrm{SD}$ & & 3.8 & 0.78 & 6.1 & 4.39 & 29.6 & 1.41 & 1.36 & 8.97 & 11.17 \\
\hline Carboy 95-1 & Whole & 5 & 4.13 & 10.1 & 41.5 & 121 & 1.64 & 27.30 & 3.98 & 66.10 \\
\hline $\operatorname{Bag} 95-12^{\circ}$ & $<0.8 \mu \mathrm{m}+2^{\circ} \mathrm{C}$ & 6 & 1.50 & 6.7 & 10.9 & 35.3 & na & na & na & na \\
\hline Bag 95-1 & $<0.8 \mu \mathrm{m} 0^{\circ} \mathrm{C}$ & 6 & 1.50 & 5.1 & 10.9 & 73.7 & na & na & na & na \\
\hline Bag 95-2 & $<0.8 \mu \mathrm{m}$ & 5 & 1.60 & 10.2 & 12.5 & 71.8 & na & nd & na & na \\
\hline Bag 95-3 & $<0.8 \mu \mathrm{m}$ & 6 & 3.20 & 11.8 & 16.6 & 78.9 & 0.88 & 9.66 & 2.74 & 30.22 \\
\hline Mean & All treatments & 5.6 & 2.4 & 8.8 & 18.5 & 76.7 & 1.26 & 18.48 & 3.36 & 48.16 \\
\hline SD & & 0.5 & 1.1 & 2.5 & 11.7 & 27.2 & 0.38 & 8.82 & 0.62 & 17.94 \\
\hline \multicolumn{11}{|c|}{$\begin{array}{l}\text { ¿Duration of initial exponential growth phase of experiment after Day } 0 \text {, determined by day maximum cell number is } \\
\text { reached before any decline } \\
\text { bFinal minus initial value } \\
\text { cExcluding value for } 94-1\end{array}$} \\
\hline
\end{tabular}

images, which avoids the large errors derived from cubing linear dimensions. Usually $>300$ cells were measured for each volume estimate. Bacterial abundance/size samples were not replicated.

TdR and Leu incorporation assays were carried out in refrigerated circulator baths held at the carboy incubation temperatures using high specific activity tritiated substrates (NEN). Final concentrations were 10 to $20 \mathrm{nM}$ for $\mathrm{TdR}$ and $20 \mathrm{nM}$ for Leu. In 1994, we processed samples by vacuum filtering 40 to $50 \mathrm{ml}$ through $0.45 \mu \mathrm{m}$ cellulose ester membranes as described earlier (Ducklow et al. 1995). In 1995 we followed the microcentrifugation protocol described by Smith \& Azam (1992) to minimize isotope usage and waste production and to lower blank values and improve sensitivity. In this method $1.7 \mathrm{ml}$ samples are incubated in $2 \mathrm{ml}$ plastic screw-capped centrifuge tubes held in the bath in floating racks. Samples in both years were incubated for 2 to $24 \mathrm{~h}$, depending on anticipated incorporation rates, in water in refrigerated circulator baths. Triplicate subsamples and zero-time blanks were run for all samples. All samples were extracted 3 times in cold 5\% TCA and rinsed with $80 \%$ ethanol before liquid scintillation counting (LSC) in Packard Ultima Gold cocktail. All LSC counting was completed on board the ship.

$\mathrm{Chl} a$, particulate matter and DOC were analyzed as described elsewhere (Smith et al. 1998). DOC analyses on whole water samples or $0.8 \mu \mathrm{m}$ filtrates from the incubation vessels were performed following gravity filtration of small volumes through precombusted $\mathrm{GF} / \mathrm{F}$ filters (Carlson et al. 1998).

Data analysis. Incorporation rates were calculated from the mean of each 3 subsamples minus the zerotime blank value and converted to pmol $\mathrm{l}^{-1} \mathrm{~h}^{-1}$ rates assuming no isotope dilution. Simon \& Azam (1989) determined that isotope dilution for ${ }^{3} \mathrm{H}$-leucine varied from 0 to 2 -fold off coastal California. We were not able to estimate isotope dilution in our work, and report the observed values for consistency with other reports. Assuming a 2-fold dilution would double the rates reported here, while halving the conversion factors. Empirical determination of conversion factors corrects for unknown dilution variations (Kirchman et al. 1982). The bacterial biovolume in each sample is the product of measured abundance and mean cell volume. Specific rates of increase of abundance, biovolume and incorporation rates in the carboys and bags were calculated from Model I regressions of $\ln$ (property) versus time over appropriate intervals. In some cases, incorporation rates were not monitored throughout the duration of the experiment (e.g. cf. Figs. 1 \& 3). For purposes of comparing slopes of increases in cells, biovolume and incorporation rates, slopes were calculated over the same intervals (starting at $t=0$, ignoring any apparent lag periods). Significance of regression coef- 
ficients and equality among different slopes were determined using $t$-tests (Edwards 1984). Conversion factors for deriving bacterial production estimates from TdR and Leu incorporation rates were derived from Model I or II linear regressions of cumulative cell production on cumulative incorporation over appropriate incubation intervals (Bjørnsen \& Kuparinen 1991, see below).

\section{RESULTS}

\section{Environmental conditions, bacterial abundance and incorporation rates}

These experiments were conducted in the late spring (1994) and summer (1995-96) in the Ross Sea, spanning the period of the Phaeocystis antarctica bloom, an annual event in this region (Smith \& Gordon 1997). Chl a levels were low (ca $2 \mu \mathrm{g} \mathrm{l}^{-1}$ ) for the
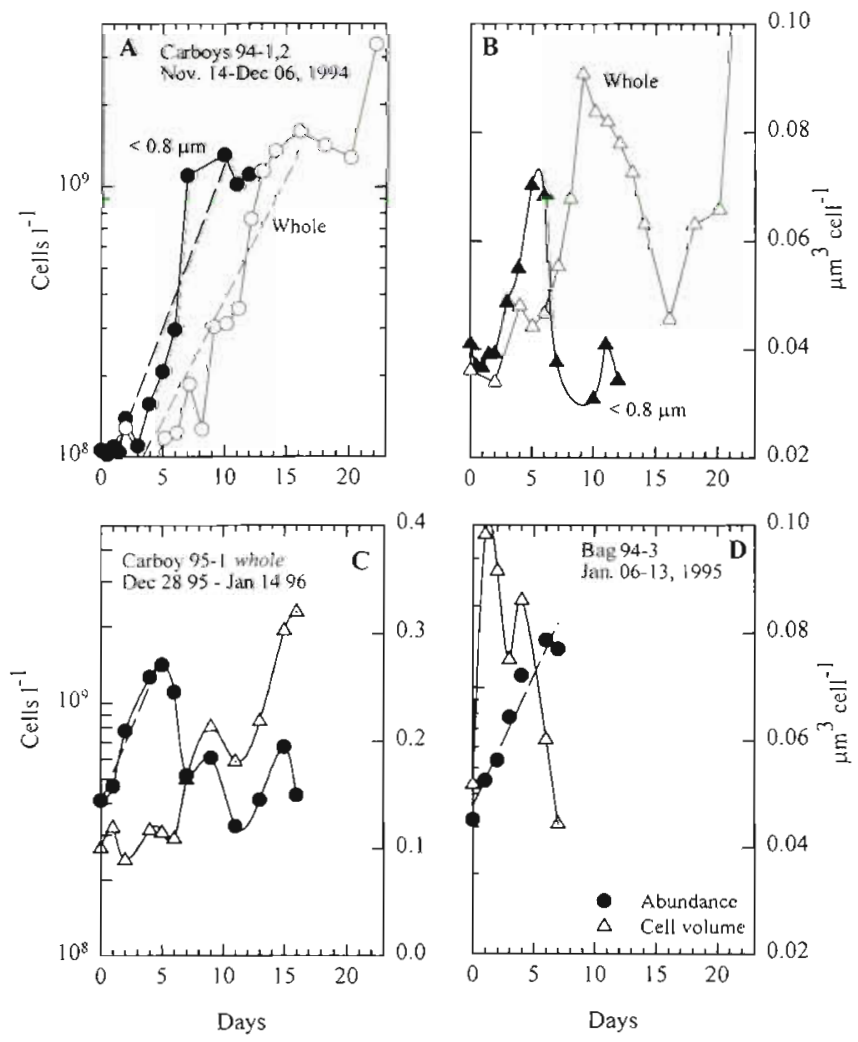

Fig. 1. Bacterial abundance and mean cell volumes during seawater culture incubations. Dashed lines: period of exponential growth over which growth rates were computed. (A) Abundance in Carboy 94-1(O) and Carboy 94-2 $(<0.8 \mu \mathrm{m}, \bullet)$ experiments. (B) Mean cell volume Carboy $94-1(\Delta)$ and Carboy $94-2(<0.8 \mu \mathrm{m}, \boldsymbol{\Delta})(\mathrm{C})$ Abundance $(\bullet)$ and cell volume $(\Delta)$ in Carboy 95-1 (whole water). (D) Abundance and cell volume in Bag 95-3 experiment
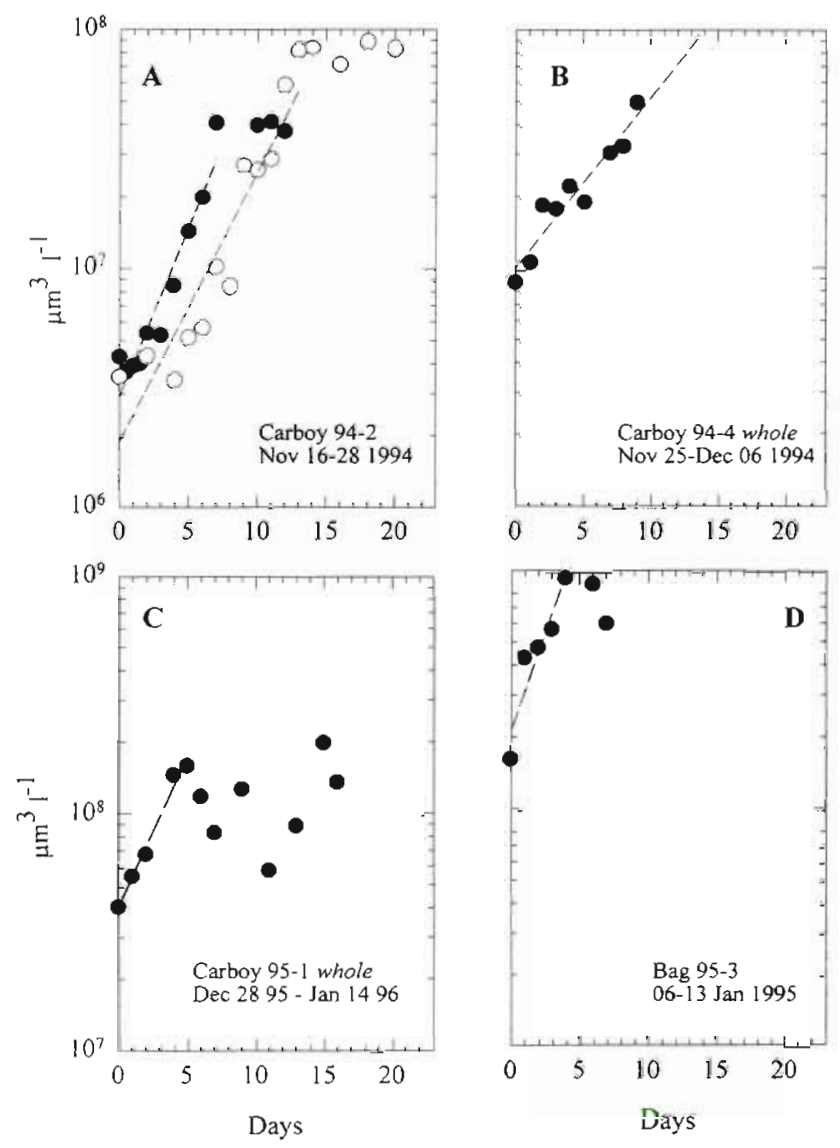

Fig. 2. Total bacterial biovolume (abundance times cell volume from Fig. 1) during seawater culture incubations. (A) Carboy 94-1 (O) and Carboy 94-2 $(<0.8 \mu \mathrm{m}$, $\bullet)$ experiments. (B) Carboy 94-4 experiment. (C) Carboy 95-1 experiment (whole water). (D) Bag 95-3 experiment

earliest and latest experiments performed, and

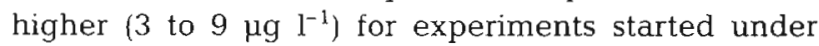
bloom conditions (Table 1). Because most experiments were started using water with high phytoplankton biomass (Smith et al. 1998) there was a mean of $22 \%$ enhancement of DOC in the $0.8 \mu \mathrm{m}$ filtrates, even though gentle gravity reverse filtration was used to prepare the samples (Table 1; Carlson et al. 1999).

Bacterial abundance was initially low in all samples, ranging from 1 to $4 \times 10^{8}$ cells $^{-1}$ (Table 2), typical of ambient levels in late spring and early summer in this region (unpubl. obs.). Incorporation rates were low to moderate, ranging from 0.2 to $4 \mathrm{pM} \mathrm{h}^{-1}$ and 1 to $27 \mathrm{pM}$ $\mathrm{h}^{-1}$ for TdR and Leu, respectively (Table 2 ). Specific incorporation rates (incorporation per cell) ranged from 1 to $25 \times 10^{-21} \mathrm{~mol} \mathrm{~h}^{-1}$ cell $^{-1}$ and 11 to $66 \times 10^{-21}$ $\mathrm{mol} \mathrm{h}^{-1} \mathrm{cell}^{-1}$ for TdR and Leu, respectively. About $10^{9}$ cells $\mathrm{l}^{-1}$ were produced in these experiments, regardless of treatment (Table 2). 

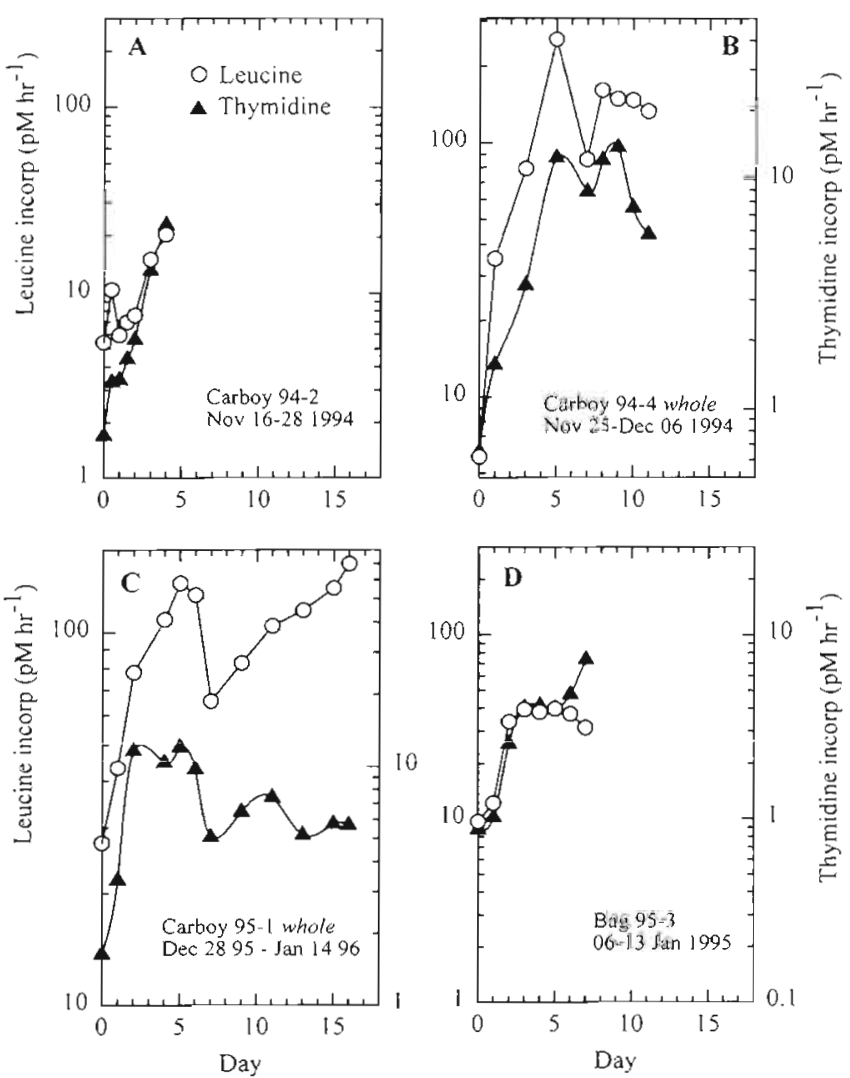

Fig. $3 .{ }^{3} \mathrm{H}$-thymidine $(\mathbf{\Delta})$ and ${ }^{3} \mathrm{H}$-leucine $(0)$ incorporation rates during seawater culture incubations in experiments as in Fig. 2

\section{Growth dynamics in cultures}

Cells grew exponentially in all experiments, but for varying periods, ranging from $3 \mathrm{~d}$ in Carboy $94-5 \mathrm{~W}$ to $16 \mathrm{~d}$ in 94-1 (both whole water), and for 5 to $7 \mathrm{~d}$ in all $0.8 \mu \mathrm{m}$ filtrates before reaching a stationary phase or declining (Figs. 1, $4 \& 5$ ). There were also lags before apparent net growth began, which ranged from 0 (Figs. 1D \& 5A) to $7 \mathrm{~d}$ (Figs. 1A \& 4A). Lag periods were more common in experiments conducted earlier in the growing season (before 25 November 1994). Mean cell volume increased by a factor of 2 to 3 during growth in all experiments (Figs. 1, 4 \& 5). The combination of increases in cell number and size led to large increases in total cell biovolume (i.e. abundance $x$ mean cell volume) in some experiments (Table 2). For example, total bacterial biovolume increased by factors of 10 to 30 in 1994 (Figs. 2A, 4B \& 5C). Mean cell volume also decreased in some experiments after initial periods of enlargement, but patterns of cell enlargement and reduction did not seem to be related to sequential growth and division of cells, and increases in number.

\section{Growth rates}

Bacterial cell populations grew at 0.06 to $0.70 \mathrm{~d}^{-1}$ (mean, $0.28 \mathrm{~d}^{-1}$; Table 3 ), and bacterial biovolume increased at 0.05 to $0.65 \mathrm{~d}^{-1}$ (mean, $0.33 \mathrm{~d}^{-1}$; Table 3). Minimum generation times approached 1 to $2 \mathrm{~d}$ in both cruises, even at very low ambient temperatures. The growth rates reported in Table 3 were calculated using data from the start of each experiment, including any apparent lag phase, until the stationary phase. In some cases, growth coefficients calculated from the true exponential (straight-line) phase of the experiments were substantially greater than the rates reported here (e.g. in Fig. 1A, 0.39 vs $0.09 \mathrm{~d}^{-1}$; see 'Discussion').

\section{Incorporation rates}

TdR and Leu incorporation rates also increased exponentially during incubation in all experiments where incorporation rates were measured (Figs. 3, 4 \& 5). Increased incorporation rates would be expected during increases in abundance unless incorporation

Table 3. Slopes of regressions of $\ln$ (culture properties) on incubation time. Regression coefficients are significant $(p<0.05)$ unless noted (ns). Entries with different superscripts (within experiments only) differ from each other at $p<0.05$. Experiments with no superscripts do not differ from each other significantly $(p>0.05)$. nd: not determined

\begin{tabular}{|c|c|c|c|c|c|}
\hline Expt & & $\begin{array}{l}\text { Cells } \\
\left(d^{-1}\right)\end{array}$ & $\begin{array}{l}\text { Cell } \\
\text { volume ir } \\
\left(\mathrm{d}^{-1}\right)\end{array}$ & $\begin{array}{c}\text { TdR } \\
\text { incorp. } \\
\left(\mathrm{d}^{-1}\right)\end{array}$ & $\begin{array}{l}\text { Leucine } \\
\text { incorp. } \\
\left(\mathrm{d}^{-1}\right)\end{array}$ \\
\hline Carboy $94-1$ & $\begin{array}{c}\text { Slope } \\
\text { SE }\end{array}$ & $\begin{array}{l}0.200 \\
0.030\end{array}$ & $\begin{array}{l}0.264 \\
0.027\end{array}$ & $\begin{array}{l}\text { nd } \\
\text { nd }\end{array}$ & $\begin{array}{l}\text { nd } \\
\text { nd }\end{array}$ \\
\hline Carboy 94-2 & $\begin{array}{l}\text { Slope } \\
\text { SE }\end{array}$ & $\begin{array}{l}0.089^{\circ} \\
0.036 \text { (ns) }\end{array}$ & $\begin{array}{l}0.182^{d, c} \\
\text { s) } 0.045\end{array}$ & $\begin{array}{l}0.639^{\mathrm{b}} \\
0.047\end{array}$ & $\begin{array}{l}0.305^{\mathrm{c}} \\
0.088\end{array}$ \\
\hline Carboy 94-3 & $\begin{array}{l}\text { Slope } \\
\text { SE }\end{array}$ & $\begin{array}{l}0.149^{\mathrm{d}} \\
0.046\end{array}$ & $\begin{array}{l}0.288^{a} \\
0.051\end{array}$ & $\begin{array}{l}0.759^{b} \\
0.054\end{array}$ & $\begin{array}{l}0.564^{\mathrm{b}} \\
0.077^{2}\end{array}$ \\
\hline Carboy $94-3 \mathrm{G}$ & $\begin{array}{l}\text { Slope } \\
\text { SE }\end{array}$ & $\begin{array}{l}0.097^{2} \\
0.032\end{array}$ & $\begin{array}{l}0.238 \\
0.040\end{array}$ & $\begin{array}{l}0.624^{c} \\
0.054\end{array}$ & $\begin{array}{l}0.579^{c} \\
0.073\end{array}$ \\
\hline Carboy $94-4$ & $\begin{array}{c}\text { Slope } \\
\text { SE }\end{array}$ & $\begin{array}{l}0.518 \\
0.090\end{array}$ & $\begin{array}{l}0.648 \\
0.063\end{array}$ & $\begin{array}{l}0.555 \\
0.160\end{array}$ & $\begin{array}{l}\text { nd } \\
\text { nnd }\end{array}$ \\
\hline Carboy $94-52^{\circ}$ & $\begin{array}{c}\text { - Slope } \\
\text { SE }\end{array}$ & $\begin{array}{l}0.704 \\
0.094\end{array}$ & $\begin{array}{l}0.654 \\
0.051\end{array}$ & $\begin{array}{l}0.659 \\
0.278\end{array}$ & $\begin{array}{l}\text { nd } \\
\text { nd }\end{array}$ \\
\hline Carboy $94-5 W$ & $\begin{array}{l}\text { Slope } \\
\text { SE }\end{array}$ & $\begin{array}{l}0.143 \\
0.028\end{array}$ & $\begin{array}{l}0.054 \\
0.062(\mathrm{~ns})\end{array}$ & $\begin{array}{l}\text { nd } \\
\text { nd }\end{array}$ & $\begin{array}{l}\text { nd } \\
\text { nd }\end{array}$ \\
\hline Carboy 94-5 & $\begin{array}{c}\text { Slope } \\
\text { SE }\end{array}$ & $\begin{array}{l}0.062^{d} \\
0.022 \text { (ns) }\end{array}$ & $\begin{array}{l}0.161^{d} \\
0.038\end{array}$ & $\begin{array}{l}0.555^{b} \\
0.038\end{array}$ & $\begin{array}{l}0.680^{b} \\
0.138\end{array}$ \\
\hline Carboy 95-1 & $\begin{array}{l}\text { Slope } \\
\text { SE }\end{array}$ & $\begin{array}{l}0.266 \\
0.028\end{array}$ & $\begin{array}{l}0.289 \\
0.022\end{array}$ & $\begin{array}{l}0.360 \\
0.118\end{array}$ & $\begin{array}{l}0.31 .6 \\
0.051\end{array}$ \\
\hline Bag 95-1 & $\begin{array}{l}\text { Slope } \\
\text { SE }\end{array}$ & $\begin{array}{l}0.265 \\
0.052\end{array}$ & $\begin{array}{l}0.326 \\
0.035\end{array}$ & $\begin{array}{l}\text { nd } \\
\text { nd }\end{array}$ & $\begin{array}{l}\text { nd } \\
\text { nd }\end{array}$ \\
\hline Bag 95-1 $2^{\circ}$ & $\begin{array}{l}\text { Slope } \\
\text { SE }\end{array}$ & $\begin{array}{l}0.404 \\
0.068\end{array}$ & $\begin{array}{l}0.338 \\
0.050\end{array}$ & $\begin{array}{l}\text { nd } \\
\text { nd }\end{array}$ & $\begin{array}{l}\text { nd } \\
\text { nd }\end{array}$ \\
\hline Bag 95-2 & $\begin{array}{l}\text { Slope } \\
\text { SE }\end{array}$ & $\begin{array}{l}0.404 \\
0.039\end{array}$ & $\begin{array}{l}0.401 \\
0.026\end{array}$ & $\begin{array}{l}\text { nd } \\
\text { nd }\end{array}$ & $\begin{array}{l}\text { nd } \\
\text { nd }\end{array}$ \\
\hline Bag 95-3 & $\begin{array}{l}\text { Slope } \\
\text { SE }\end{array}$ & $\begin{array}{l}0.304 \\
0.019\end{array}$ & $\begin{array}{l}0.378 \\
0.083\end{array}$ & $\begin{array}{l}0.448 \\
0.082\end{array}$ & $\begin{array}{l}0.392 \\
0.102\end{array}$ \\
\hline All expts & $\begin{array}{l}\text { lean slope } \\
\text { SD }\end{array}$ & $\begin{array}{l}0.277 \\
0.181\end{array}$ & $\begin{array}{l}0.325 \\
0.165\end{array}$ & $\begin{array}{l}0.575 \\
0.118\end{array}$ & $\begin{array}{l}0.473 \\
0.142\end{array}$ \\
\hline
\end{tabular}


per cell declined. However, incorporation rates showed a tendency to increase faster than abundance or biovolume in about half the experiments (mean rates of increase 0.47 to $0.58 \mathrm{~d}^{-1}$ ) indicating concomitant increases in specific incorporation rates (Table 3 and see below). There were no marked lag phases in incorporation rates.

\section{Effects of size fractionation, temperature and organic matter addition}

We examined the effects of size fractionation, which removes bacteriovores as well as new DOM sources from samples, by comparing growth in whole water with that in $0.8 \mu \mathrm{m}$ filtrates. The results did not show a consistent effect of size fractionation. Cells in

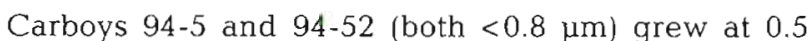
and $0.7 \mathrm{~d}^{-1}$ while Carboy $94-5 \mathrm{~W}$ grew at just $0.14 \mathrm{~d}^{-1}$ (Fig. 5). The whole water sample reached stationary phase $3 \mathrm{~d}$ earlier than the $0.8 \mu \mathrm{m}$ samples, and cell
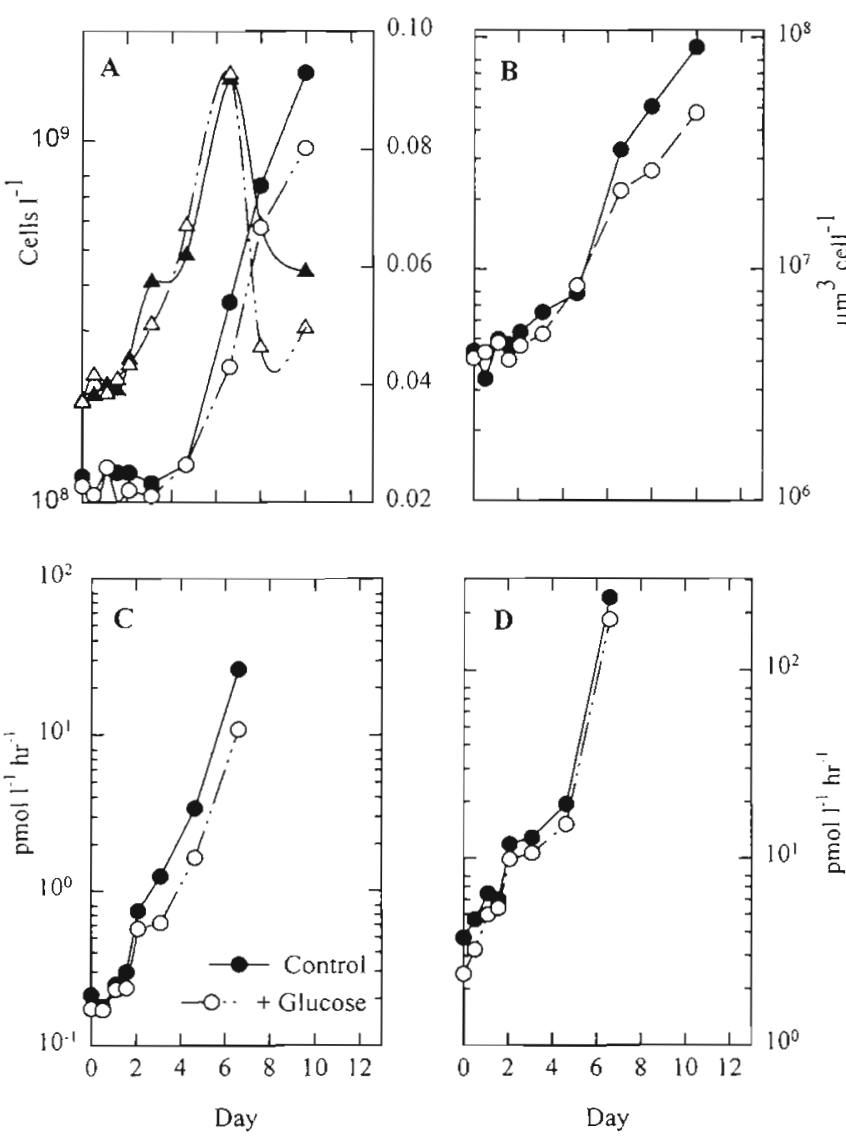

Fig. 4. Bacterial properties during seawater culture experiment Carboy $94-3(<0.8 \mu \mathrm{m})$. $(\bullet, \mathbf{\Delta})$ Control experiment; $(0$, $\Delta)$ glucose addition. (A) Abundance $(\bullet, 0)$ and mean cell volume $(\Delta, \Delta)$. (B) Total biovolume. (C) ${ }^{3} \mathrm{H}$-thymidine and (D) ${ }^{3}$ H-leucine incorporation rates
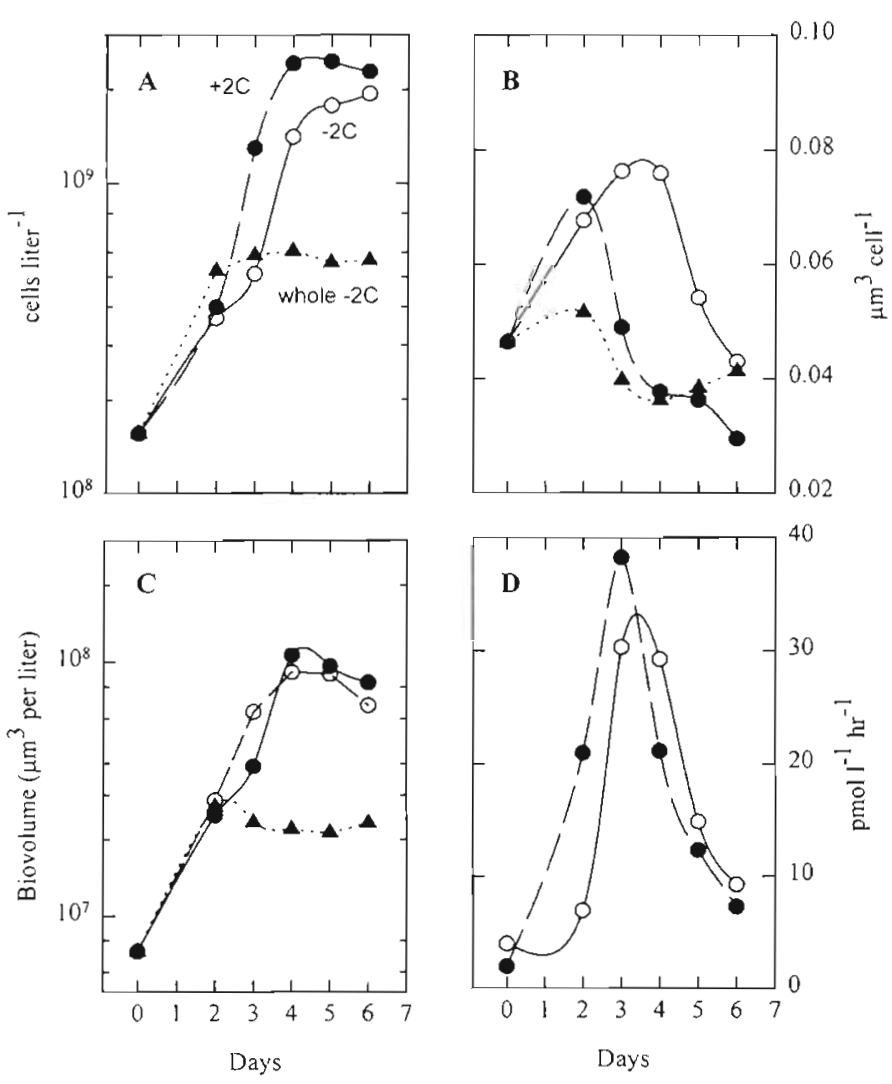

Fig. 5. Bacterial properties during seawater culture experiment Carboy 94-5. (•) $<0.8 \mu \mathrm{m},+2{ }^{\circ} \mathrm{C}$; (O) $<0.8 \mu \mathrm{m},-2^{\circ} \mathrm{C}$; (^) whole water, $-2^{\circ} \mathrm{C}$. (A) Abundance. (B) Mean cell volume. (C) Total biovolume. (D) ${ }^{3} \mathrm{H}$-thymidine incorporation rates

volumes did not increase, suggesting bacteriovores may have cropped larger cells selectively in this experiment (Fig. 5A,B). In Carboy 94-1 (whole water) cells grew at $0.20 \mathrm{~d}^{-1}$, whereas in Carboy 94-2 $(<0.8 \mu \mathrm{m})$, started $2 \mathrm{~d}$ later, cells grew at $0.09 \mathrm{~d}^{-1}$. Possibly because of large daily variability in Carboy 94-2, these growth rates did not differ significantly ( $p>0.05$; Table 3 ). The latter comparison is possibly complicated because the whole treatment was incubated in the light, but in general, bacteria grew at substantial rates even in whole water, indicating that bacterivory and other removal processes did not balance growth.

Temperature effects were examined directly in Carboy 94-5 and Bag 95-1 (Table 3, Fig. 5). In neither case did an increase to $+2^{\circ} \mathrm{C}$ (higher than the seasonal maximum observed in the southern Ross Sea) cause significant increases in growth rate ( $t$-test, $\mathrm{p}>0.05$ ). Finally, in a single experiment, $10 \mu \mathrm{M}$ glucose (i.e. $60 \mu \mathrm{M} \mathrm{C}$ ) was added to Carboy 2G (Fig. 4). Glucose addition did not cause an increase in growth rate, incorporation or cell yield over the control. Both the control and glucose-amended samples had en- 


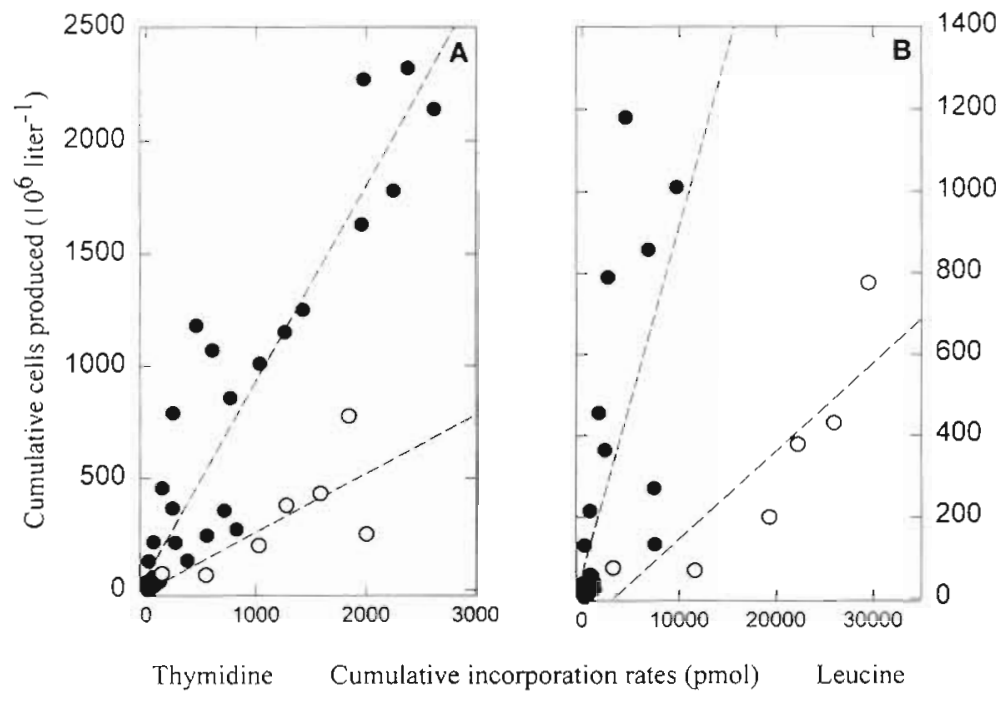

Fig. 6. (A) Thymidine and (B) leucine conversion factor plots (cumulative change in cell abundance vs integrated incorporation). (---) Linear regressions through all points shown (slope is conversion factor in cells per mol). See Tables 1 to 3 for details of experiments and designations. (O) Carboy 94-4 experiment, (-) combined data from all other experiments

per unit incorporation). The combined data for both years indicate a uniform relationship with cell production, except for the Carboy 94-4 experiment (Fig. 6, open circles). The Model I regression slope for the main body of thymidine data (Fig. 6A, closed circles) was $8.69 \pm 0.55 \times 10^{17}$ cells $\mathrm{mol}^{-1}\left(\mathrm{r}^{2}=0.88, \mathrm{n}=35\right)$. The relationship between leucine and cells divided into 2 distinct groups with much lower cell production per unit incorporation (i.e. a lower CF) for the Carboy 94-4 experiment (Fig. $6 B$, open circles). Slopes for the 2 leucine plots were $8.53 \pm 1.96 \times 10^{16}$ cells $\mathrm{mol}^{-1}\left(\mathrm{r}^{2}\right.$ $=0.46, \mathrm{n}=24$, closed circles), and $2.16 \pm$ $0.49 \times 10^{16}$ cells mol $^{-1}\left(r^{2}=79, n=7\right.$, open circles). All intercepts were not significantly different from zero. The Carboy 94 4 experiment was initiated with an inoculum of high-Phaeocystis surface water in deep, $\mathrm{NO}_{3}$-rich water to stimulate a new bloom. This may explain the anomalous results for this experiment. Individual CF values for $\mathrm{TdR}$ and Leu (Fig. 7) averaged

hanced natural DOC as a result of sample prefiltration (Table 1; see 'Discussion' and Carlson et al. 1999).

These experiments were not sufficiently comprehensive to justify any general conclusions, but taken together, they suggest that bacterial cells were growing at substantial rates, and were not consistently affected by bottom-up (glucose, temperature) or topdown (grazing) controls during the study period.

\section{Conversion factors}

Cumulative cell production was well-correlated with integrated thymidine and leucine incorporation rates in most experiments, suggesting consistent relationships between these processes (Fig. 6A,B). The analyses were carried out using the full time course of measured incorporation in each experiment, extending through lag, $\log$ and stationary phases of growth. We used the cumulative method of computing the $\mathrm{TdR}$ and Leu conversion factors (CF) of Bjørnsen \& Kuparinen (1991) because it employs all the data. In this approach the CF value is the slope of the cumulative cells versus incorporation plot (i.e. cells produced
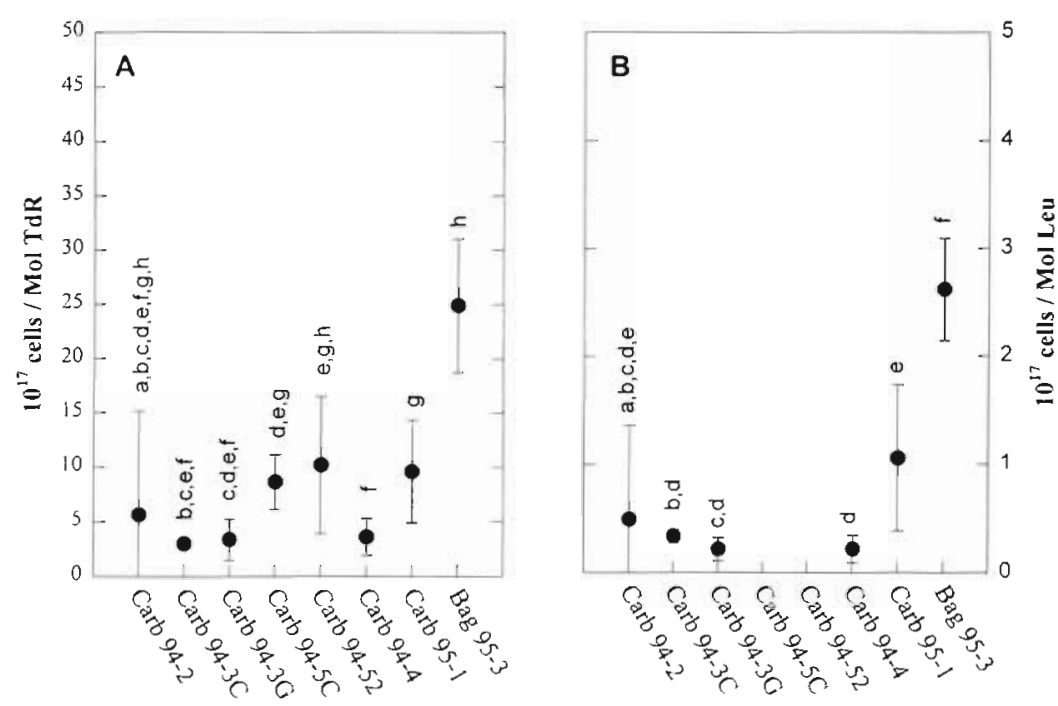

Fig. 7. (A) Thymidine and (B) leucine conversion factors determined from slopes of individual plots of cumulative cell production versus cumulative incorporation rates. Bars are $95 \%$ confidence intervals. Values do not differ significantly between experiments sharing letters above bars ( $t$-test, $p>0.05)$. Experiment designations as in Table 1 
$\mathrm{mol}^{-1}$ Leu for the 2 cruises combined, values larger than reported by Bjørnsen \& Kuparinen (1991), perhaps because of the increases in mean cell size during experiments.

\section{DISCUSSION}

Because the aim of these experiments was to provide insight into bacterial growth and production rates occurring in situ, we wish to know how representative the incubations were of water column processes. DOC enrichment during preparation of the $0.8 \mu \mathrm{m}$ filtrates is a potential complicating factor in assessing this issue. DOC concentration increased by an average of $9.3 \mu \mathrm{mol} C(22 \%)$ in the 7 size-fractionated experiments (Table 1). Large DOC increases (>1 $\mu_{\mathrm{mol} \mathrm{l}}^{-1}$ ) were not observed following gentle GF/F filtration of small volumes in preparation for routine DOC analysis of ambient water column samples (Carlson et al. 1999) but filtration of large volumes of water through Nuclepore filters must have caused cellular and colonial breakage and release of DOM. Carboy $94-5$ is the single direct comparison between unenriched (whole) and enriched $(<0.8 \mu \mathrm{m})$ samples. In this experiment the whole, unenriched sample grew at $0.52 \mathrm{~d}^{-1}$, while the enriched sample grew at $0.14 \mathrm{~d}^{-1}$, suggesting growth rate enhancement by DOM enrichment. The comparison is complicated by possible effects of grazer suppression in the whole sample compared to the filtered sample (see 'Discussion' above). Two other experiments with whole unenriched samples grew at 0.20 and $0.27 \mathrm{~d}^{-1}$ while the mean growth rate of $<0.8 \mu \mathrm{m}$ filtrates enriched with DOC was $0.30 \mathrm{~d}^{-1}$. Overall, that is, the $<0.8 \mu \mathrm{m}$ samples with enhanced DOM grew at rates no faster than whole samples without enhanced DOM and with potentially heavier removal of bacteria by grazers. We suggest that bacteria in the $0.8 \mu \mathrm{m}$ filtrates were growing on a suite of DOM compounds similar to those supplied by intact populations of Phaeocystis antarctica and other plankton in the whole water preparations (Smith et al. 1998, Carlson et al. 1999).

The incubations, especially early in the first cruise, had apparent lag periods of several days before exponential growth was apparent (e.g. Figs. 1A \& 4A). There are several possible explanations for these 'lags'. Morita (1997) has suggested that most, if not all, marine bacterioplankton exist predominantly in a state of dormancy, under severe carbon and/or energy starvation. He suggests further that measurements of bacterial activity such as the ones we performed are artifacts of unwitting enrichment with lab and ship-related contaminants (e.g. volatile organics, plastic leachates). In Morita's view the apparent 'lag' period is actually the true reflection of processes occurring in the natural system, whereas the subsequent growth is a response to the contamination of the experimental cultures. In general we do not accept this argument because it is inconsistent with the existence of intensive bacterivory in natural plankton assemblages, which would tend to remove dormant cells from the water. It is possible that in the Ross Sea, when bacteriovore populations are low, dormant cells might be maintained in the water column. Finally we observed a seasonal evolution in the occurrence and length of apparent lag periods, which is not consistent with Morita's more sweeping generalization.

Another possibility is that the apparent lag phase is a reflection of logistic ('S-shaped') growth curves (Gause 1934, Wright \& Coffin 1984), and some of our experiments do show superficial resemblance to logistic growth (Fig. 1A). This possibility is practically impossible to evaluate because of the difficulty of estimating the carrying capacity at which growth levels off in the absence of grazers and viruses (Ducklow \& Hill 1985a), but it cannot be easily falsified either.

A third scenario, originally proposed by Kirchman et al. (1982, and cf. Wright \& Coffin 1984, Ducklow \& Hill 1985a), and more recently exarnined by others (Torreton \& Dufour 1996) concerns the hypothetical existence of nondividing subpopulations of cells which are progressively overgrown by the growing populations. This scenario requires that nongrowing cells remain nongrowing in culture even after culture enrichment. In most cases in which bacterial growth in seawater cultures has been studied this scenario has not been addressed directly, for example using autoradiography or vital stains like CTC. Choi et al. (1996, their Fig. 3A) show results from a seawater culture incubation with total (DAPI) and 'active' (CTC-stained) cell counts. The total counts have an apparent lag period similar to those we observed while the CTC counts grew without lag and converged with the total counts, consistent with the 'inactive subpopulation' model. Estimates of active subpopulation sizes in our experiments can be obtained by extrapolating the linear portion of the growth response back to time zero. Using this approach we could estimate that the apparent active fraction was 20 to $40 \%$ of the total population in $<0.8 \mu \mathrm{m}$ filtrates of whole samples in early November 1994 , increasing to $100 \%$ in December 1995 to January 1996 when there were no lags observed in the cultures. However, without independent confirmation by staining techniques we cannot substantiate this speculation. Further, maintenance of constant-sized inactive populations in the water in the presence of grazers and elevated DOM remains difficult to explain unless there was a substantial exchange between active and inactive populations. 
It is also possible that instead of having large fractions of the bacterial assemblage being nongrowing, that the bacterial assemblage consists of distinct subpopulations growing at different rates. For a pair of populations $N_{1}, N_{2}$ growing exponentially at rates $\mu_{1}$ and $\mu_{2}$, the equation for growth of the total population is:

$$
N_{\text {Tot }}=N_{1} \mathrm{e}^{\mu_{1} t}+N_{2} \mathrm{e}^{\mu_{2} t}
$$

(The nongrowing scenario just discussed is a special case with $\mu_{2}=0$.) The graph of Eq. (1) is curvilinear with an apparent lag phase when plotted in semilog fashion if the smaller of the 2 populations is growing more rapidly than the larger. Fig. 8 shows a pair of populations with $\mu_{1}: \mu_{2}=15$ where $N_{1}$ is initially $10 \%$ of the total population. This example is scaled to approximate the observed growth in the Carboy 94-1 experiment (Fig. 1), from which the abundance data are plotted. In this experiment, the entire bacterial assemblage grew at $0.09 \mathrm{~d}^{-1}$ over the first $4 \mathrm{~d}$ (Table 3 ). Between Days 3 and 10 the assemblage grew at $0.39 \mathrm{~d}^{-1}$, as indicated by the $N_{1}$ line, which is parallel to the regression of $\ln$ (abundance) versus time for Days 3 to 10 . In sum of exponential growth, the apparent growth rate of the total assemblage in the later stages of the experiment approaches the growth rate of the faster growing subpopulation as the latter increasingly dominates the

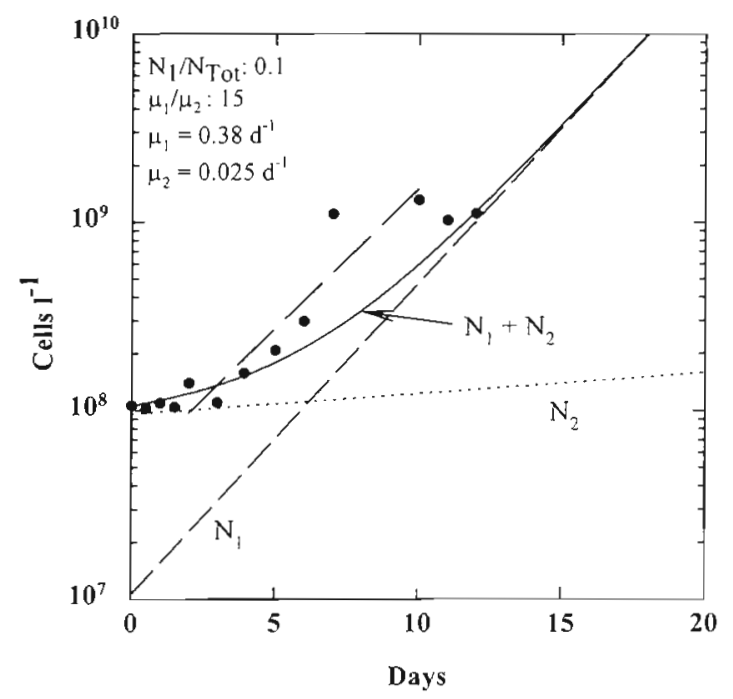

Fig. 8. Growth of a hypothetical bacterial assemblage with 2 subpopulations ( $N_{1}$, and $N_{2}$ growing exponentially at 0.38 and $0.025 \mathrm{~d}^{-1}$,respectively, with $N_{1}$ making up $10 \%$ of the total abundance at time = zero. $(--\ldots, \cdots)$ Growth of each population; (-) their sum; (-) observed abundances from the Carboy 94-1 experiment (Fig. 1A); (_ - - slope $0.38 \mathrm{~d}^{-1}$ is the regression of the Carboy $94-1$ data during its exponential growth phase. Parameters for $\mu_{1} / \mu_{2}$ and $N_{1} /\left(N_{1}+\right.$ $N_{2}$ ) were adjusted to provide the best visual fit to the Carboy 94-1 data, with $\mu_{1}=0.38$ and $N_{1}+N_{2}=1.06 \times 10^{8}$ cells l$^{-1}$ assemblage. This model can be empirically fit to the growth curves we observed, and can account for the apparent lags in the experiments. The possible existence of 2 or more distinct subpopulations is consistent with recent molecular taxonomic analyses of seawater cultures (Carlson \& S. Giovononni unpubl. data).

Specific growth rates for bacterial assemblages utilizing natural DOM sources in the absence of predators ranged from 0.09 to $0.70 \mathrm{~d}^{-1}$. Growth rates were low (0.09 to $0.15 \mathrm{~d}^{-1}$ in cultures started early in the Phaeocystis antarctica bloom [before 25 November; Tables 1 \& 3] and 0.26 to $0.70 \mathrm{~d}^{-1}$ during the peak and declining stages of the bloom [30 November to 6 January]). Culture growth rates were low when primary production was 0.3 to $2 \mathrm{~g} \mathrm{C} \mathrm{m}^{-2} \mathrm{~d}^{-1}$ in early November, and higher when primary production was 2 to $5 \mathrm{~g} \mathrm{C} \mathrm{m}^{-2} \mathrm{~d}^{-1}$ in late November to early December 1994. Growth rates were also 0.2 to $0.5 \mathrm{~d}^{-1}$ in later December 1995 to early January 1996, during the declining phase of the $P$. antarctica bloom (Smith \& Gordon 1997, Carlson et al. 1998), which complicates simple regression comparisons with ambient chl. This pattern suggests that the bacterial assemblages evolved in response to the course of the $P$. antarctica bloom, having at least potentially low growth rates under pre-bloom and early bloom conditions, and potentially greater rates during the peak and decay phases of the bloom.

Bacteria grew at net rates of 0.06 to $0.26 \mathrm{~d}^{-1}$ even in untreated, unamended 'whole' seawater, in the presence of other plankton, including abundant populations of choanoflagellates in 1995-96 (Ducklow \& E. Lessard unpubl. obs.). Bacterial biomass in these experimental plankton cultures dominated by Phaeocystis antarctica grew exponentially but never amounted to more than $2 \%$ of the total particulate carbon in the cultures (Smith et al. 1998). Nonetheless, significant net growth rates indicated that growth was in excess of removal and mortality in all cases. Furthermore, growth rates up to $0.7 \mathrm{~d}^{-1}$ in $<0.8 \mu \mathrm{m}$ filtrates indicate that mortality caused by lytic bacteriophage was minor, or alternatively, that intrinsic growth rates were even greater than observed.

Bacterial growth rates and patterns observed in these cultures incubated at -2 to $+2^{\circ} \mathrm{C}$ were similar to rates obtained in other growth experiments in Antarctic waters. Hanson et al. (1983) performed the first modern seawater culture experiments in Southern Ocean waters in October 1980 between $50^{\circ}$ and $60^{\circ} \mathrm{S}$. Their cultures grew exponentially with $1 \mathrm{~d}$ apparent lag periods. Most of their experiments were performed in subantarctic waters at 2 to $5^{\circ} \mathrm{C}$, but growth rates in $<3 \mu \mathrm{m}$ unenriched samples from the Polar Front Zone in the Drake Passage ranged from 0.4 to $1 \mathrm{~d}^{-1}$, as judged visually from their Fig. 7. Similarly, Bjørnsen \& Kuparinen (1991) and Kuparinen \& Bjørnsen (1992), 
working in the Scotia and Weddell Seas near $57^{\circ}$ to $61^{\circ} \mathrm{S}$, obtained growth rates of 0.3 to $0.7 \mathrm{~d}^{-1}$ in $<0.8 \mu \mathrm{m}$ filtrates. They also observed apparent lag phases ranging from 0 to $4 \mathrm{~d}$ in their cultures, followed by several days of exponential growth (judged from data in their Table 2 replotted in log scale). Growth rates were 0.2 to $0.3 \mathrm{~d}^{-1}$ in whole water. Kahler et al. (1997) observed rates of 0.14 to $0.17 \mathrm{~d}^{-1}$ in unenriched $<0.8 \mu \mathrm{m}$ filtrates from $56^{\circ} \mathrm{S}, 6^{\circ} \mathrm{W}$ (Antarctic circumpolar current in the South Atlantic) with no lag period. Furthermore, their samples grew linearly. This is not uncommon, but cannot be explained mathematically in terms of simple assumptions about microbial growth. At low growth rates, and with few data points, it is not possible statistically to distinguish between linear and exponential growth (Ducklow \& Hill 1985a). Our experiments are the first known growth experiments from the interior of the MIZ of the Ross Sea, a particle-dominated system in latitudes with about 5 mo of darkness, an intense phytoplankton bloom and low DOC accumulation (Smith \& Gordon 1997, Carlson et al. 1998). The resulting growth rates are in the same range as samples from waters experiencing some solar irradiance year-round, and waters outside the MIZ.

Bacteria in these samples also grew at rates not greatly slower than has been observed in cultures from lower latitude, warmer regimes. Rivkin et al. (1996) analyzed the relationship between bacterial growth rate and temperature, dividing studies into groups from waters $<4$ or $>4^{\circ} \mathrm{C}$. The 231 rate estimates analyzed were from water column measurements of bacterial abundance combined with production estimates from $\mathrm{TdR}$ incorporation, rather than from direct observations of growth. Rate estimates were highly dependent on the thymidine conversion factor used (theoretical or empirically derived values, T-TCF and E-TCF, respectively), so the findings were not directly comparable with culture data. However, rates estimated using E-TCFs were derived from culture experiments, and thus bear some relationship to direct growth observations (Ducklow \& Carlson 1992). For waters in the -2 to $+2^{\circ} \mathrm{C}$ range, $\mathrm{E}-$ TCF-derived growth rates ranged from ca 0.1 to $2 \mathrm{~d}^{-1}$. The calculated means for T-TCF values from $<4$ and $>4^{\circ} \mathrm{C}$ were 0.39 and $0.41 \mathrm{~d}^{-1}$, respectively. Rate data from seawater dilution cultures performed using subtropical and north temperate Atlantic Ocean samples, temperatures 14 to $28^{\circ} \mathrm{C}$, and tropical and subpolar North Pacific samples, temperatures 6 to $28^{\circ} \mathrm{C}$ all fall within this range (Ducklow \& Hill 1985a, Kirchman 1990, Ducklow et al. 1992, Carlson \& Ducklow 1996). Direct observations of bacterial growth, which do not rely on assumptions or derived factors, all suggest that bacterial growth rates in samples taken from cold, seasonally ice-covered oceans are no different from rates measured elsewhere in the open sea.
Finally we return to the problem of how these observations are extrapolated to water column conditions. The connection is made via empirically derived factors used to convert water column rates of thymidine and/or leucine incorporation to bacterial production. In 8 experiments reported here the mean values for $E$ TCF and E-LCF (the leucine factor) were $8.6 \pm 1.3 \times$ $10^{17}$ and $8.2 \pm 0.84 \times 10^{16}$ cells produced per mole of precursor incorporated, respectively (Fig. 7). The biomass conversion factor for leucine was $4.7 \pm 0.88 \times 10^{15}$ cells produced per mole. Rivkin et al. (1996) reported a mean E-TCF for waters $<4^{\circ} \mathrm{C}$ worldwide of $8.9 \times 10^{18}$, an order of magnitude greater than our mean value. Rivkin et al. (1996) also reported E-TCF values of 2.8 to

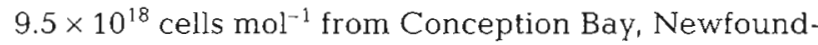
land, when temperatures were below $1.2^{\circ} \mathrm{C}$. They observed that E-TCF has a strong inverse relationship to temperature. In Antarctic waters Bjornsen \& Kuparinen (1991) reported values of 0.65 to $3.18 \times 10^{18}$ cells $\mathrm{mol}^{-1}$ thymidine and 4.9 to $9.5 \times 10^{15} \mathrm{\mu m}^{3} \mathrm{~mol}^{-1}$ leucine incorporated. Lochte et al. (1997) reported a value of $1 \times 10^{18}$, but gave no details of the experimental procedures. Similarly, Billen \& Becquevort (1991) reported a single value of $5 \times 10^{18}$ without providing details of the derivation.

The problem of deriving bacterial production estimates from isotopic incorporation experiments has not been solved. Although Rivkin et al. (1996) provide strong support for validity of high values, there are sufficient observations of low ECFs to question this generality. It is certainly clear, however, that production estimates should not be based strictly on theoretical or literature values if at all possible. The value of a CF is dependent to some extent on the method used to derive it (Kirchman \& Ducklow 1993), unless rates of incorporation increase at the specific growth rate of the cells or biovolume. If incorporation increases faster than abundance or biomass, for example, slopes of plots like Fig. 6 will be lower, yielding low CF values. CF calculated using the derivative and modified derivative approaches (Ducklow \& Hill 1985b, Kirchman \& Ducklow 1993) will be higher, especially if incorporation increases in a curvilinear manner. Most values reported and discussed here were derived using the cumulative approach, however, suggesting high values are not strictly artifacts of the deriving model employed.

The high growth rates and low CF values reported here lend support to the conclusions reported recently by Carlson et al. (1998) and Smith et al. (1998). They reported that bacterioplankton were generally a minor component of plankton biomass during massive blooms of Phaeocystis antarctica in the Ross Sea polynya. We show that they exhibit rapid growth in cold water, which is not balanced by grazers or viruses. 
High growth rates compensate for low biomass to enhance production rates. We suggest that high bacterioplankton growth rates may facilitate control of DOC accumulation during the $P$. antarctica bloom, as suggested by Carlson et al. (1998).

Acknowledgements. We gratefully acknowledge the dedicated support extended by Captain Joe Borkowski and the officers and crew of RVIB 'Nathaniel B. Palmer', and by Antarctic Support Associates, including Bruce Grainger, Buzz Scott, Rhonda Kelly, Cory Peterson and especially Steve Kottmeier. Expert technical assistance was provided by Helen Quinby, Alison Bryant-Sanford, Matthew Church, Flynn Cunningham and Ann-Maree White. This work was supported by NSF Grants OPP9319222 to H.D., 9317200 to D. Hansell and C.C. and 9317587 to W.S.

\section{LITERATURE CITED}

Ammerman JW, Fuhrman JA, Hagstrom A, Azam F (1984) Bacterioplankton growth in seawater: I. Growth kinetics and cellular characteristics in seawater cultures. Mar Ecol Prog Ser 18:31-39

Azam F, Smith DC, Hollibaugh JT (1991) The role of the microbial loop in Antarctic pelagic ecosystems. Polar Res 10:239-243

Bjørnsen PK, Kuparinen J (1991) Determination of bacterioplankton biomass, net production and growth efficiency in the Southern Ocean. Mar Ecol Prog Ser 71:185-194

Billen G, Becquevort S (1991) Phytoplankton-bacteria relationship in the Antarctic marine ecosystem. Polar Res 10: $245-253$

Carlson CA, Ducklow HW (1996) Growth of bacterioplankton and consumption of dissolved organic carbon in the Sargasso Sea. Aquat Microb Ecol 10:69-85

Carlson CA, Ducklow HW, Smith WO, Hansell DA (1998) Carbon dynamics during spring blooms in the Ross Sea polynya and the Sargasso Sea: contrasts in dissolved and particulate organic carbon partitioning. Limnol Oceanogr 43:375-386

Carlson CA, Bates NR, Ducklow HW, Hansell DA (1999) Estimation of bacterial respiration and growth efficiency in the Ross Sea, Antarctica. Aquat Microb Ecol 19:229-244

Choi JW, Sherr EB, Sherr BF (1996) Relation between presence-absence of a visible nucleiod and metabolic activity in bacterioplankton cells. Limnol Oceanogr 41:1161-1168

DeMaster DJ, Nelson DM, Harden SL, Nittrouer CA (1991) The cycling and accumulation of biogenic silica and organic carbon in Antarctic deep-sea and continental margin environments. Mar Chem 35:489-502

Ducklow HW, Carlson CA (1992) Oceanic bacterial productivity. In: Marshall KC (ed) Advanced microbial ecology Vol 12. Plenum, New York, p 113-181

Ducklow HW, Hill S (1985a) The growth of heterotrophic bacteria in the surface waters of warm core rings. Limnol Oceanogr 30:241-262

Ducklow HW, Hill S (1985b) Tritiated thymidine incorporation and the growth of bacteria in warm core rings. Limnol Oceanogr 30:263-274

Ducklow HW, Kirchman DL, Quinby HL (1992) Bacterioplankton cell growth and macromolecular synthesis in seawater cultures during the North Atlantic spring phytoplankton bloom, May 1989. Microb Ecol 24:125-144
Ducklow HW, Quinby HL, Carlson CA (1995) Bacterioplankton dynamics in the equatorial Pacific during the $1992 \mathrm{El}$ Niño. Deep-Sea Res II 42:621-638

Edwards AL (1984) An introduction to linear regression and correlation. Freeman, San Francisco

Gause GF (1934) The struggle for existence. Dover, New York (1971 reprint)

Hanson RB, Shafer D, Ryan T, Pope DH, Lowery HK (1983) Bacterioplankton in Antarctic Ocean waters during late austral winter: abundance, frequency of dividing cells, and estimates of production. Appl Environ Microbiol 42: $1622-1632$

Kahler P, Bjørnsen PK, Lochte K, Antia A (1997) Dissolved organic matter and its utilization by bacteria during spring in the Southern Ocean. Deep-Sea Res II 44:341-353

Karl DM (1993) Microbial processes in the Southern Oceans. In: Friedmann EI (ed) Antarctic microbiology. Wiley, New York, p 1-63

Kirchman DL (1990) Limitation of bacterial growth by dissolved organic matter in the subarctic Pacific. Mar Ecol Prog Ser 62:47-54

Kirchman DL, Ducklow HW (1993) Estimating conversion factors for the thymidine and leucine methods for measuring bacterial production. In: Kemp P, Sherr BF, Sherr E, Cole JJ (eds) Handbook of methods in microbial ecology. Lewis Publ, Boca Raton, p 513-518

Kirchman DL, Ducklow HW, Mitchell R (1982) Estimates of bacterial growth from changes in uptake rates, biomass. Appl Environ Microbiol 44:1296-1307

Kuparinen J, Bjøernsen PK (1992) Bottom-up and top-down controls of the microbial food web in the Southern Ocean: experiments with manipulated microcosms. Polar Biol 12: 189-195

Lancelot C, Keller MD, Rousseau V, Smith WO Jr, Mathot S (1998) Autecology of the marine haptophyte Phaeocystis sp. In: Anderson DM, Cembella AD. Hallegraff GM (eds) Physiological ecology of harmful algal blooms. NATO ASI Series, Vol G41, Springer Verlag, Heidelberg, p 209-224

Lochte K, Bjornsen PK, Giesenhagen H, Weber A (1997) Bacterial standing stock and production and their relation to phytoplankton in the Southern Ocean. Deep-Sea Res II 44 : $321-340$

Mantoura RFC, Martin JM, Wollast R (1991) Ocean margin processes in global change. Wiley, Chichester

Monta RY (1997) Bacteria in oligotrophic environments. Starvation-survival lifestyle. Chapman and Hall, New York

Rivkin RB, Anderson MR, Lajzerowicz C (1996) Microbial processes in cold oceans. 1. Relationship between temperature and bacterial growth rate. Aquat Microb Ecol 10: $243-254$

Sarmiento JL, Le Quére C (1996) Oceanic carbon dioxide uptake in a model of century-scale global warming. Science 274:1346-1350

Sarmiento JL, Toggweiler JR (1.984) A new model for the role of the oceans in determining atmospheric $\mathrm{pCO}_{2}$. Nature 308:621-624

Sedwick P, DiTullio G (1997) Regulation of algal blooms in Antarctic shelf waters by the release of iron from melting sea ice. Geophys Res Lett 24:2515-2518

Simon M. Azam F (1989) Protein content and protein synthesis rates of planktonic marine bacteria. Mar Ecol Prog Ser 51:201-213

Smith DC, Azam F (1992) A simple, economical method for measuring bacterial protein synthesis rates in seawater using ${ }^{3} \mathrm{H}$-leucine. Mar Microb Food Webs 6:107-114

Smith SV, Hollibaugh JT (1993) Coastal metabolism and the oceanic organic carbon balance. Rev Geophys 31:75-89 
Smith WO Jr, Gordon LI (1997) Hyperproductivity of the Ross Sea (Antarctica) polynya during austral spring. Geophys Res Lett 24:233-236

Smith WO Jr, Nelson DM (1985) Phytoplankton bloom produced by a receding ice edge in the Ross Sea: spatial coherence with the density field. Science 227:163-166

Smith WO, Carlson CA, Ducklow HW, Hansell D (1998) Large-volume experiments with natural assemblages of Phaeocystis antarctica from the Ross Sea. Mar Ecol Prog Ser 168:229-244

Sullivan CW, Arrigo KR, MCClain CR, Comiso JC, Firestone

Editorial responsibility: David Karl,

Honolulu, Hawaii, USA
$\mathrm{J}$ (1993) Distributions of phytoplankton blooms in the Southern Ocean. Science 262:1832-1837

Torreton JP, Dufour P (1996) Bacterioplankton production determined by DNA synthesis, protein synthesis and frequency of dividing cells in Tuamoto Atoll lagoons and surrounding oceans. Microb Ecol 32:185-203

Wright RT, Coffin RB (1984) Factors affecting bacterioplankton density and productivity in salt marsh estuaries. In Klug MJ, Reddy CA (eds) Current perspectives in microbial ecology. Am Soc Microbiologists, Washington, DC p $485-94$

Submitted: May 26, 1998; Accepted: December 28, 1998 Proofs received from author(s): September 23, 1999 